\title{
Edge effects confirmed at the clear-cut area of Korean red pine forest in Uljin, eastern Korea
}

Song Hie Jung ${ }^{1}$, Chi Hong Lim², A Reum Kim¹, Dong Min Woo ${ }^{1}$, Hye Jin Kwon ${ }^{3}$, Yong Chan Cho ${ }^{4}$ and Chang Seok Lee 5* $^{*}$

\begin{abstract}
Background: Forest edges create distinctive ecological space as adjacent constituents, which distinguish between different ecosystems or land use types. These edges are made by anthropogenic or natural disturbance and affects both abiotic and biotic factors gradually. This study was carried out to assess edge effects on disturbed landscape at the pine-dominated clear-cut area in a genetic resources reserve in Uljin-gun, eastern Korea. This study aims to estimate the distance of edge influence by analyzing changes of abiotic and biotic factors along the distance from forest edge. Further, we recommend forest management strategy for sustaining healthy forest landscapes by reducing effects of deforestation.
\end{abstract}

Results: Distance of edge effect based on the abiotic factors varied from 8.2 to $33.0 \mathrm{~m}$. The distances were the longest in $\mathrm{Mg}^{2+}$ content and total nitrogen, $\mathrm{K}^{+}, \mathrm{Ca}^{2+}$ contents, canopy openness, light intensity, air humidity, $\mathrm{Na}^{+}$ content, and soil temperature followed. The result based on biotic factors varied from 6.8 to $29.5 \mathrm{~m}$, coverage of tree species in the herb layer showed the longest distance and coverage of shrub plant in the herb layer, evenness, species diversity, total coverage of herb layer, and species richness followed. As the result of calculation of edge effect by synthesizing 26 factors measured in this study, the effect was shown from $11.0 \mathrm{~m}$ of the forest interior to $22.4 \mathrm{~m}$ of the open space. In the result of stand ordination, Rhododendron mucronulatum, R. schlippenbachii, and Fraxinus sieboldiana dominated arrangement of forest interior sites and Quercus mongolica, Vitis amurensis, and Rubus crataegifolius dominated spatial distribution of the open area plots.

Conclusions: Forest interior habitat lies within the influence of both abiotic and biotic edge effects. Therefore, we need a forest management strategy to sustain the stability of the plant and further animal communities that depend on its stable conditions. For protecting forest interior, we recommend selective logging as a harvesting method for minimizing edge effects by anthropogenic disturbance. In fact, it was known that selective logging contributes to control light availability and wind regime, which are key factors affecting microclimate. In addition, ecological restoration applying protective planting for the remaining forest in the clear-cut area could contribute to prevent continuous disturbance in forest interior.

Keywords: Clear cut, Disturbance, Ecological restoration, Edge effect, Pinus densiflora

\footnotetext{
*Correspondence: leecs@swu.ac.kr

${ }^{5}$ Division of Chemistry and Bio-Environmental Sciences, Seoul Women's

University, Seoul 139-774, South Korea

Full list of author information is available at the end of the article
} 


\section{Background}

Forest edges create distinctive ecological space as adjacent constituents, which distinguish between different ecosystems or land use types. These edges are made by anthropogenic or natural disturbance and affects both abiotic and biotic factors gradually (Harper et al. 2004). Edge effects can have serious impacts on species diversity and composition, community dynamics, and ecosystem functioning (Saunders et al. 1991, Laurance et al. 2006). Many edge effects are variable in space and time (Ewers and Didham 2006).

The influence of the adjacent non-forest environment on forest structure and species composition at created edges is now widely recognized. The altered habitat may be contributing to forest degradation and the loss of biodiversity in fragmented landscapes (Saunders et al. 1991, Gascon et al. 2000, Laurance et al. 2002).

Forest edges are becoming more abundant in many regions around the world because of the loss of forest arising from human activity, including settlement, agriculture, resource extraction, and timber harvesting. Most of all, clear cutting is a controversial forest management tool. It can create early successional habitats and edge areas at a landscape scale, which are preferred by many species (Pykälä 2004), while creating also a large portion of the landscape, which experiences edge effects (Keenan and Kimmins 1993). The edge effect has been a major topic of interest in studies of the landscape patterns and processes associated with edge creation and fragmentation during the last few decades (Harper et al., 2005).

Negative effects of edge creation have become apparent, including structural damage (Laurance et al. 1998) and depressed breeding success of songbirds (Gates and Gysel 1978) at forest edges. More recently, studies on changes at forest edges have revealed that edge effect can lead to the degradation of forest fragments (Gascon et al. 2000, Laurance et al. 2002). These negative consequences have fostered much interest in edges and fragmentation in conservation biology (Harper et al., 2005).

The strength of edge effects diminishes as one moves to deeper inside forests, but in addition, many edge phenomena vary markedly even within the same habitat fragment or landscape. Factors that might promote edge-effect variability include the age of habitat edges (Matlack 1993), edge aspect (Turton and Freiburger 1997), fragment size (Ewers et al. 2007), the structure of the adjoining matrix vegetation (Pohlman et al. 2007), seasonality (Young and Mitchell 1994), extreme weather events (Laurance et al. 2001), and fires (Cochrane and Laurance 2002).

To assess edge effects on disturbed landscape, several studies have estimated the magnitude of edge influence along the distance from forest edge (Harper and Macdonald 2011, Harper et al. 2015) and developed statistical methodology for calculating the distance of edge influence (Wales 1972, MacQuarrie and Lacroix 2003).

The majority of current researches on edge effect focused on proving differences along an interior-edgeexterior gradient and changes of species composition after clear cutting into early successional stage in Korea (Park et al. 2010, Ming et al. 2013, Kim 2010, Kim 2014). These researches designate arbitrary blocks and thus exclude a series of continuous environmental gradients. Any studies on the distance of edge influence, which a given variable is significantly different from the interior forest, were not carried out to date.

First of all, we aim to analyze changes of abiotic and biotic factors along the distance from forest edge in the forest area disturbed by clear-cut. Second, we aim at estimating the distance of edge influence by synthesizing those data. Based on our finding, we recommend forest management strategy for reducing effects of deforestation and thus recovering healthy forest landscapes.

\section{Methods \\ Site description and data collection}

The study was conducted in a harvest area of forest genetic resource reserves in Uljin-gun, eastern Korea. Mean annual precipitation and temperature of this region are $1119 \mathrm{~mm}$ and $12.6{ }^{\circ} \mathrm{C}$, respectively (Korea Meteorological Administration 2011). The geology is Precambrian granite gneiss (Park and Yoon 1968). Plants of northern and southern provinces appear together due to topographical features connected to the high mountains called "Baekdudaegan." The forest landscape of this study area is dominated by Korean red pine (Pinus densiflora for. Erecta) forest and Mongolian oak (Quercus mongolica) forest. The former is dominated by Korean red pine and Acer pseudosieboldianum, Rhododendron schlippenbachii, Rhododendron mucronulatum, and so on, appear in undergrowth. The latter is dominated by Mongolian oak and Styrax obassia, Lespedeza cyrtobotrya, Lindera obtusiloba, and so on, grow as undergrowth.

The study area is located in $37^{\circ} 1^{\prime} 56.22^{\prime \prime} \mathrm{N}$ and $129^{\circ}$ $12^{\prime} 4.65^{\prime \prime}$ E geographically and at an elevation of approximately $690 \mathrm{~m}$ above sea level on NE aspects topographically (Fig. 1). Harvesting was conducted by applying a clear-cut method in 2013. Areal size that clear-cut is executed amounts to 1.54 ha. We carried out a field survey from May to September 2016. Spatial range for field survey includes the forest edge and interior and exterior of the forest.

We established five $80-\mathrm{m}$-long belt transects with $5-\mathrm{m}$ breadth perpendicular to forest edge, which are extended to $40 \mathrm{~m}$ toward both directions of the forest interior and the harvest area. Belt transects were placed next to each other. Along each transect, we established $5 \mathrm{~m} \times 5 \mathrm{~m}$ plots at the following distances from the edge: $-38 \mathrm{~m}$ (C5), $-25 \mathrm{~m}(\mathrm{C} 4)$, 


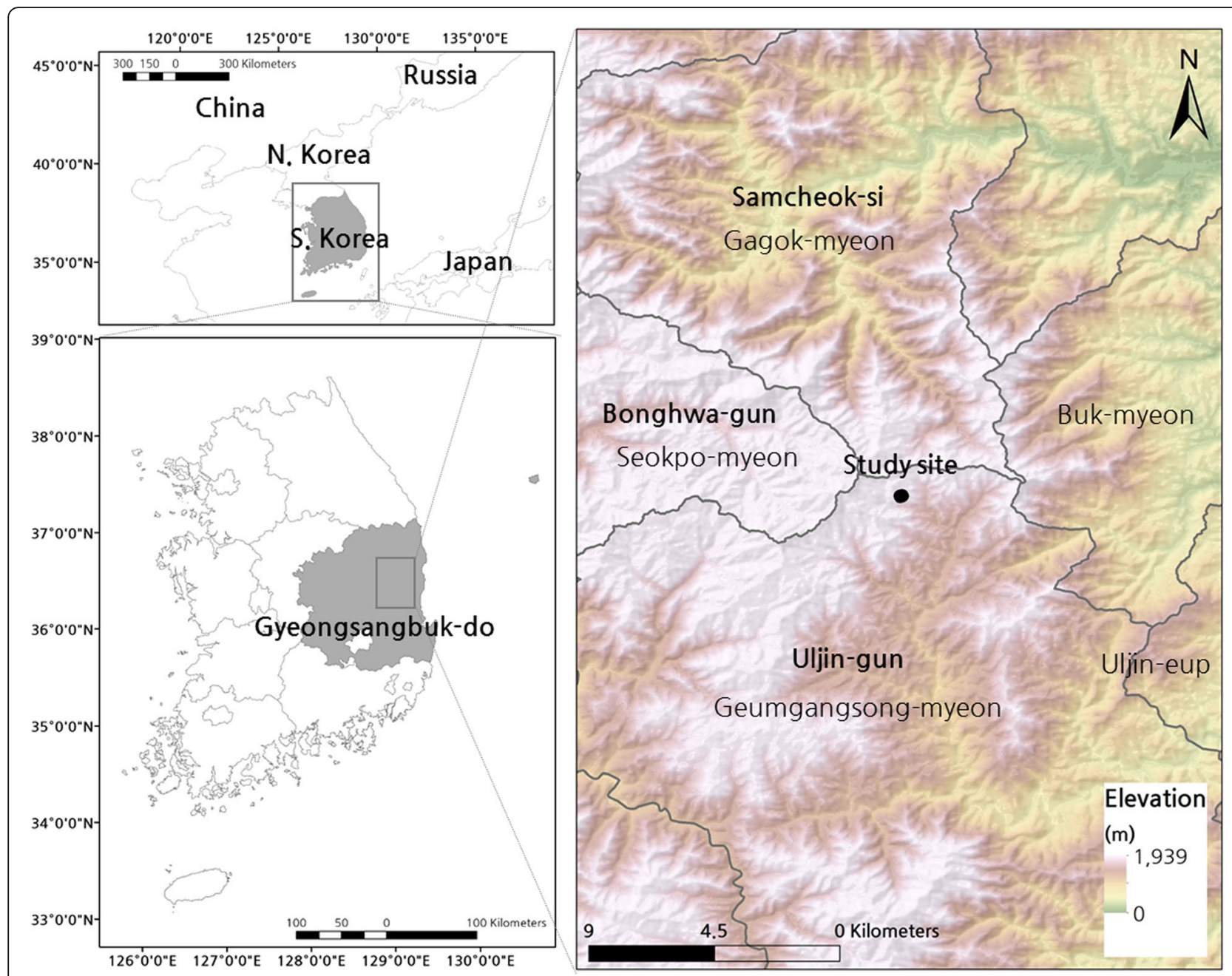

Fig. 1 A map showing the geographic location of study area

$-16 \mathrm{~m}(\mathrm{C} 3),-9 \mathrm{~m}(\mathrm{C} 2),-3 \mathrm{~m}(\mathrm{C} 1), 3 \mathrm{~m}(\mathrm{O} 1), 9 \mathrm{~m}(\mathrm{O} 2)$, $16 \mathrm{~m}(\mathrm{O} 3), 25 \mathrm{~m}(\mathrm{O} 4)$ and $38 \mathrm{~m}(\mathrm{O} 5)$ (negative distances represent them within forest interior) (Fig. 1).

\section{Measurement of abiotic factors \\ Microclimate}

We installed meteorological sensors (Model HOBO Pro v2 U23-001, U23-004, Onsetcompany, Bourne, USA) on $1 \mathrm{~m}$ above ground and under $15 \mathrm{~cm}$ below ground at each distance to measure air temperature, air humidity, and soil temperature during the growing season. Each sensor was protected from direct sunlight by a protective case and observations were made at 30-min intervals. Soil humidity was measured during the same period with the other microclimatic factors and observed at 10-min intervals with a moisture probe (Pico Trime HD2, AGEON, Germany).

\section{Canopy openness and light availability}

Canopy openness and light availability were calculated using imaging software (GAP Light Analyzer 2.0) to extract canopy structural parameters and gap light transmission indices from true-color fisheye photographs (Nikon D80 digital camera, Sigma 4.5, F 2.8 EX DC Circular Fisheye HSM lens). All hemispherical fisheye photographs were taken from $1 \mathrm{~m}$ above ground at the center of plots.

\section{Physicochemical properties of soil}

Soil samples were collected from plots at all distance. In each distance, soil samples were collected in June 2016 from the top $10 \mathrm{~cm}$ at five random points in each plot, pooled, air-dried under the shaded condition, and sieved though 2-mm mesh. pH was measured in a 1:5 mixture of soil and distilled water then measuring after agitation using a pH meter (MAPA 1994). Total nitrogen and available phosphate were measured according to the Walkley and Black method (Walkely and Black 1934) and Lancaster method (Murphy and Riley 1962). Cation exchange capacity (CEC) and exchangeable bases $\left(\mathrm{K}^{+}\right.$, $\mathrm{Na}^{+}, \mathrm{Ca}^{2+}$, and $\mathrm{Mg}^{2+}$ ) were determined by the 


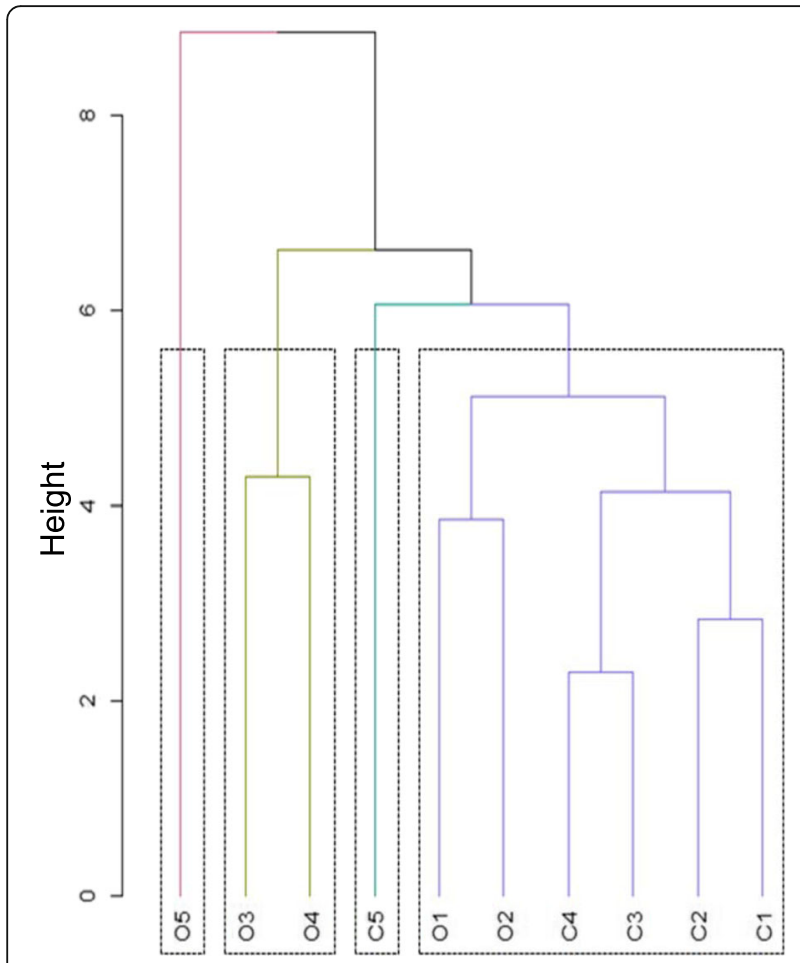

Fig. 2 A result of hierarchical clustering based on the abiotic and biotic factors (C5: $-38 \mathrm{~m}, \mathrm{C4}:-25 \mathrm{~m}, \mathrm{C3}:-16 \mathrm{~m}, \mathrm{C2}:-9 \mathrm{~m}, \mathrm{C1}:-3 \mathrm{~m}$, O1: 3 m, O2: 9 m, O3: 16 m, O4: 25 m, O5: 38 m). The optimal solution with $k=4$ is indicated by different coloring

ammonium acetate method (Chapman 1965) and atomic absorption spectrophotometry (MAPA 1994).

\section{Soil respiration}

Soil respiration was measured by applying the closed dynamic chamber method (Bekku et al. 1997) using a portable closed chamber infrared gas analysis system (SRC-1 with EGM-4, PP-Systems, Hitchin, Herts, UK). We installed six soil collars in plots of each distance. The $\mathrm{CO}_{2}$ efflux was calculated from the concentration change within the chamber headspace and measured at 2-s intervals for 2 min by applying the following equation (Eq. 1 ). Soil respiration was measured periodically in every month for 3 months from June to August. Measurement was carried out at four times duplication from 10:00 to 13:00 in all plots of each distance.

$$
\begin{aligned}
& \text { Soil respiration }\left(\mathrm{mgCO}_{2} \mathrm{~m}^{-2} \mathrm{~h}^{-1}\right) \\
& =3600 \times 10^{-6} \text { a } \rho V S^{-1}
\end{aligned}
$$

$a$ : change of $\mathrm{CO}_{2}$ concentration $\left(\mu \mathrm{mol} \mathrm{mol}{ }^{-1} \mathrm{~s}^{-1}\right)$

$$
\rho: \mathrm{CO}_{2} \text { density }\left(\mathrm{mg} \mathrm{m}^{-3}\right)
$$

$V$ : volume of the chamber $\left(\mathrm{m}^{3}\right)$

$$
S: \text { surface area }\left(\mathrm{m}^{2}\right)
$$

\section{Measurement of biotic factors Species diversity}

Shannon diversity index $\left(H^{\prime}\right)$ (Shannon and Weaver 1949, Brower and Zar 1984), richness (R) (Margalef 1958), and evenness ( $/$ ) (Pielou 1969) were calculated to evaluate changes of species diversity along the distance from forest edge using PC-Ord 4.0 (McCune and Mefford 1999). Diversity indices were calculated by applying the following equations.

$$
\begin{aligned}
& H^{\prime}=-\sum_{i} P_{i} \ln \left(P_{i}\right) \\
& R=\left(n_{i}-1\right) / \ln (N) \\
& J=H^{\prime} / H^{\prime} \max
\end{aligned}
$$

$i: 1,2,3, \ldots S$

$P_{i}$ : proportion of individuals in the $i$ th species

$n_{i}$ : number of individuals in the $i$ th species

$N$ : total number of individuals

\section{Species composition}

A crown projection diagram of herb layer was drawn for the whole study plot, which is extended over $80 \mathrm{~m} \times 25 \mathrm{~m}$ divided with a $5 \mathrm{~m} \times 5 \mathrm{~m}$ grid. All plant species appeared in each subplot were identified, following Lee (1985) and spatial range of crown that each plant covers the ground was measured using tape ruler in four directions of east, west, south, and north. The coverage of herb layer was calculated as a real size of land covered by the crown using ArcGIS program (ver. 10.0).

Vegetation survey was carried out Based on the frequency and dominance (Braun-Blanquet 1964), in $1 \mathrm{~m} \times 1 \mathrm{~m}$ subplots arranged in diagonal direction in each plot. Differences in species composition were analyzed with non-metric multidimensional scaling (NMDS) (Kruskal 1964) stand ordination based on Euclidean distance, which was performed using the function "vegan" of the $\mathrm{R}$ statistical package. The importance value of each species was fed in a matrix for NMDS ordination.

\section{Aboveground biomass}

Estimation of aboveground biomass in the herb layer was made on each subplot applying direct sampling method after vegetation survey. Aboveground of all plants appeared in each subplot was harvested, oven dried at $80{ }^{\circ} \mathrm{C}$ to constant mass (Drying Oven, Daeil Eng. DDO102), and weighted using an electronic scale (SHIMADZU EB-3200HU). 

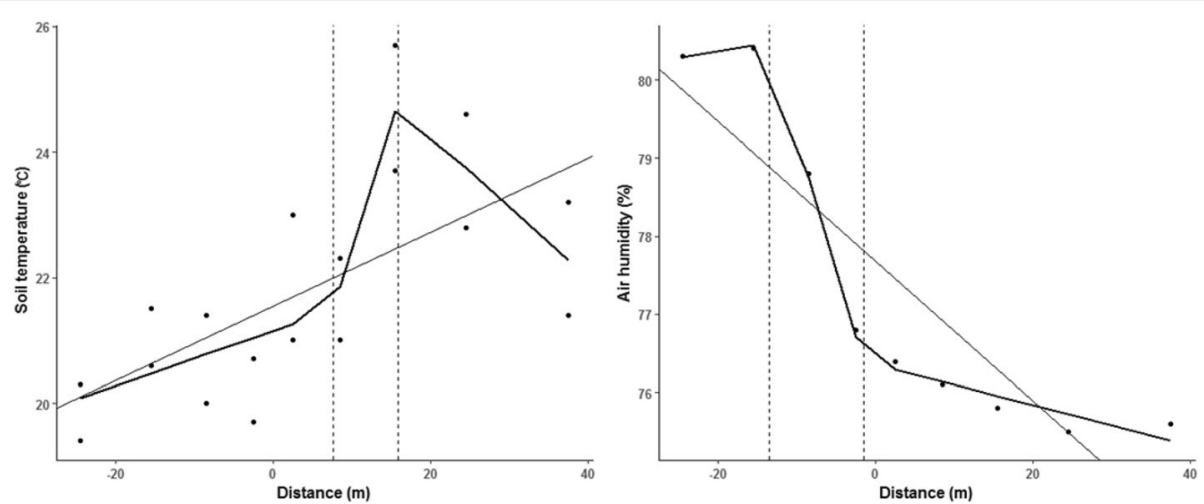

Fig. 3 Changes of soil temperature and air humidity along the distance from forest edge (soil temperature: $r^{2}=0.7318$, air humidity: $r^{2}=0.9954$, black thick line: piecewise regression, dotted line: Two break points)

\section{Edge effect}

The functions "dist" and "hclust" of the $\mathrm{R}$ statistical package (ver. 3.3.3) were used to determine inner forest plot as reference information.

Magnitude of edge influence (abbreviated as MEI hereafter) for each response variable was calculated by applying the following equation (Harper and Macdonald 2011):

$\mathrm{MEI}=\left|\frac{\bar{e}-\bar{r}}{\bar{e}+\bar{r}}\right|$

$\bar{e}$ : value of the parameter at edge

$\bar{r}$ : value of the parameter in the interior

Distance of edge influence (abbreviated as DEI hereafter) is defined as the distance that a given response variable is significantly different from the interior forest. Distance of edge influence can be calculated based on change of MEI along the distance. We calculated DEI with piecewise regression models, which make two or more lines joined at unknown points, called "breakpoints." Breakpoints can be used as estimates of thresholds (Toms and Lesperance 2003). Breakpoints are calculated using the function "segmented" of the R statistical package and displayed as dashed gray lines.

On the other hand, DEI of each environmental factor was calculated based on the actual measurement value of the factor.

\section{Results}

\section{Determination of the range of forest interior}

As the result of hierarchical clustering, the forest interior plot (C5), which is the farthest from the forest edge formed by clear cutting and the other plots of the forest interior were divided into different groups from each other (Fig. 2). Based on the result, ecological information of the forest interior plots except for C5 plot was used for calculating MEI and DEI to exclude the effects of the other environmental factors beside the edge effect.

\section{Magnitude of edge effect based on the abiotic factors}

As the result of calculation for the distance of edge effect by applying a regression analysis method (Fig. 3),
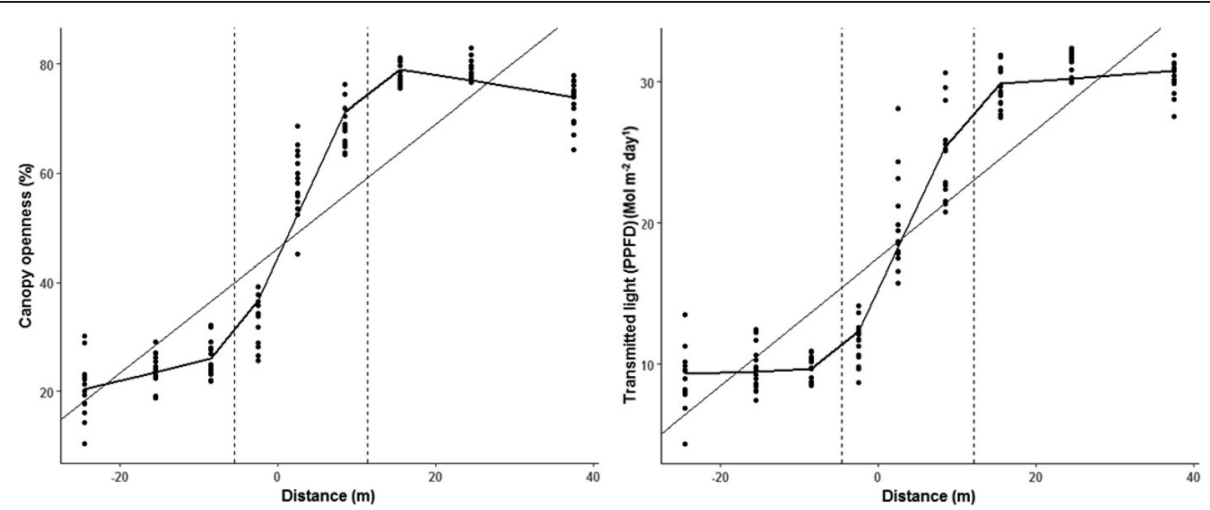

Fig. 4 Changes of canopy openness and light intensity along the distance from forest edge (canopy openness: $r^{2}=0.9623$, transmitted light: $r^{2}=0.9497$, black thick line: piecewise regression, dotted line: two break points) 

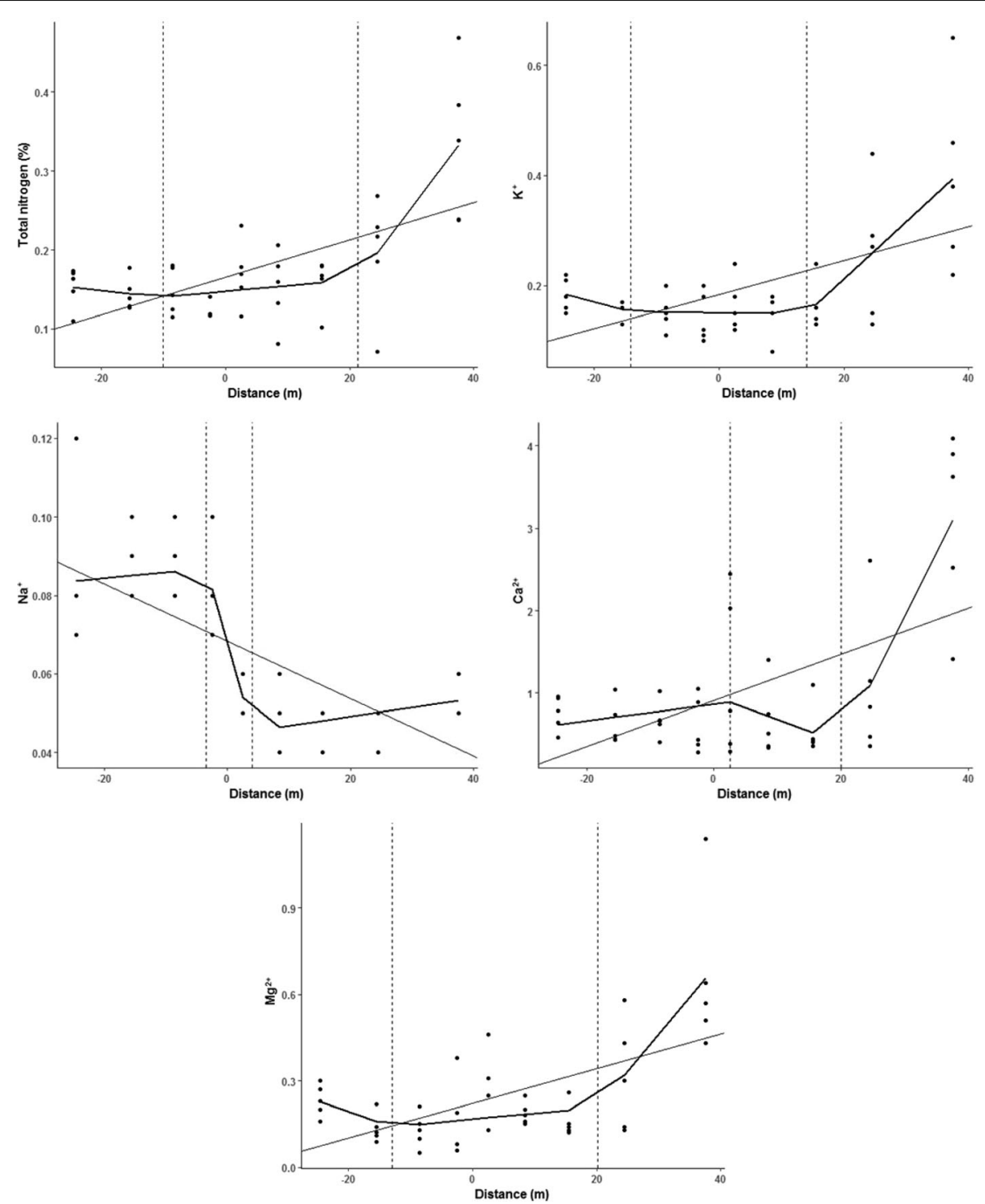

Fig. 5 A change of physicochemical properties of soil along the distance from forest edge (total nitrogen: $r^{2}=0.6148, \mathrm{~K}^{+}: r^{2}=0.5490, \mathrm{Na}$ : $r^{2}=0.7622, \mathrm{Ca}^{2+}: r^{2}=0.6207, \mathrm{Mg}^{2+}: r^{2}=0.5942$, black thick line: piecewise regression, dotted line: two break points)

soil temperature showed significant edge effect from 7.6 to $15.8 \mathrm{~m}$ in the open space by lumbering. Humidity showed significant edge effect from 1.6 to $13.6 \mathrm{~m}$ of the forest interior. Air temperature and soil moisture did not show any significant edge effect. Canopy openness showed significant edge effect from the borderline of the lumbering to 1.5 and $11.3 \mathrm{~m}$ toward the forest interior and the open area, respectively (Fig. 4). Light intensity showed edge effect from $4.7 \mathrm{~m}$ of the forest interior to $12.1 \mathrm{~m}$ of the open space (Fig. 4).

As the results of calculation based on physicochemical properties, total nitrogen, $\mathrm{K}^{+}, \mathrm{Mg}^{2+}$, and $\mathrm{Na}^{+}$showed significant edge effects from $10.0 \mathrm{~m}, 14.1 \mathrm{~m}, 12.9 \mathrm{~m}$, and $4.4 \mathrm{~m}$ of forest interior, to $21.4 \mathrm{~m}, 14.0 \mathrm{~m}, 20.1 \mathrm{~m}$, and $4.0 \mathrm{~m}$ of the open space, respectively (Fig. 5). $\mathrm{Ca}^{2+}$ showed an edge effect from $2.5 \mathrm{~m}$ to $20.0 \mathrm{~m}$ of the open space. On the other hand, $\mathrm{pH}$, available phosphorous, cation exchange capacity, and soil respiration did not show any significant effect.

\section{Distance of edge effect based on the biotic factors}

Species diversity, evenness, and richness showed the edge effects from 8.2 to $23.0 \mathrm{~m}$ in the open space, from 7.8 to $22.9 \mathrm{~m}$ in the open space, and from $3.2 \mathrm{~m}$ of the forest interior to $3.6 \mathrm{~m}$ of the open space (Fig. 6). Coverages of tree and shrub species in the herb layer showed edge effects from $7.6 \mathrm{~m}$ of the forest interior to $12.0 \mathrm{~m}$ of the forest interior (Fig. 7). On the other hand, total coverage of the herb layer showed edge effect from 1.4 to $11.9 \mathrm{~m}$ of the forest interior (Table 1). But coverage of 


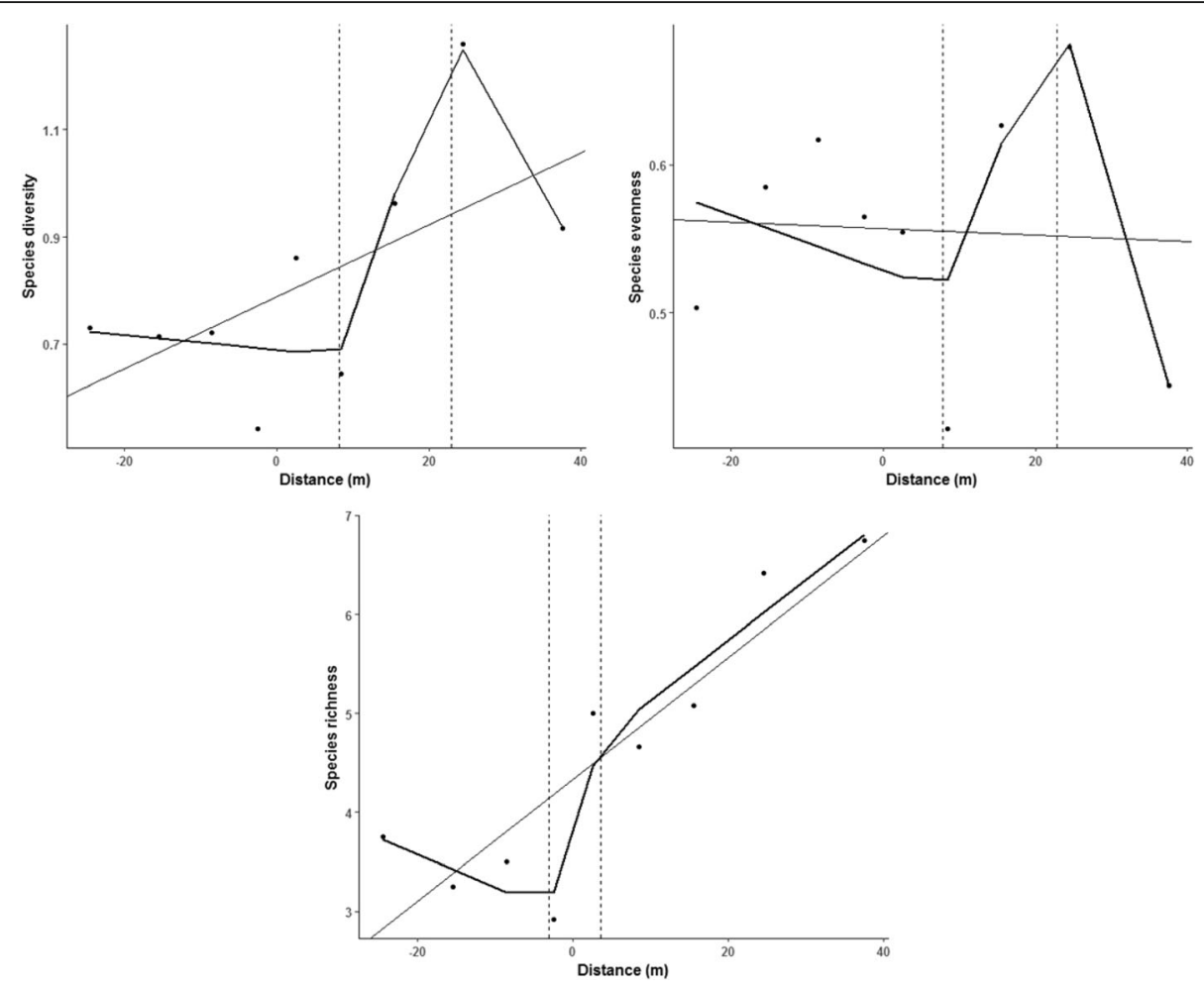

Fig. 6 Changes of species diversity, evenness and richness indices along the distance from forest edge (species diversity: $r^{2}=0.8442$, species evenness: $r^{2}=0.5901$, species richness: $r^{2}=0.9371$, black thick line: piecewise regression, dotted line: two break points)

subtree, vine, and herbaceous plants and aboveground biomass did not show any significant effect.

\section{Distance of synthetic edge effect}

As the result of calculation of edge effect by synthesizing 26 factors measured in this study, the effect was shown from $11.0 \mathrm{~m}$ of the forest interior to $22.4 \mathrm{~m}$ of the open space. In the result of calculation based on 15 factors, which showed significant effect, the effect was shown from $3.3 \mathrm{~m}$ of the forest interior to $4.0 \mathrm{~m}$ of the lumbered area (Fig. 8, Table 2).

\section{Response of species composition}

As the result of stand ordination based on vegetation data of the herb layer collected in the forest interior, edge, and lumbered area, plots of the forest interior and the open area were divided into the left and the right parts on the AXISI, respectively, and sites of the edge were arranged between them. In the result of stand ordination, Rhododendron mucronulatum, $R$. schlippenbachii, and Fraxinus sieboldiana dominated arrangement of forest interior sites and Quercus mongolica, Vitis amurensis, and Rubus crataegifolius dominated spatial distribution of the open area plots (Fig. 9).

\section{Discussion}

\section{Edge effect on abiotic factors}

Primary responses of ecological process emerge immediately due to changes in forest canopy structure. The direct effects of edge creation led to primary responses of biophysical process, which are significantly different between interior and exterior of forest (Harper and Macdonald 2001).

Among abiotic factors, air humidity and soil temperature stand as significant factors in edge effect. Air humidity began to decrease from $14 \mathrm{~m}$ within the forest and thereby reduced more than $3 \%$ in the forest edge compared with that of the forest interior. Air humidity was as low as $76 \%$ in the forest exterior compared with that of the forest interior. Soil temperature showed the opposite trend and thus increased continuously to $16 \mathrm{~m}$ in the open area (Fig. 3).

Air humidity changed rapidly but soil temperature showed a slightly different trend in edge area (Fig. 3). Although microclimate of forest interior and exterior has been compared previously (Geiger 1965, Lee 1978), it is important to consider the edge as both a separate microclimate and a climatic mediator between forest and clear-cut area. Forest edge has distinguished temperature and moisture regimes resulting from wind. As near the edge winds are weaker than in clear-cut area, this produces relative 

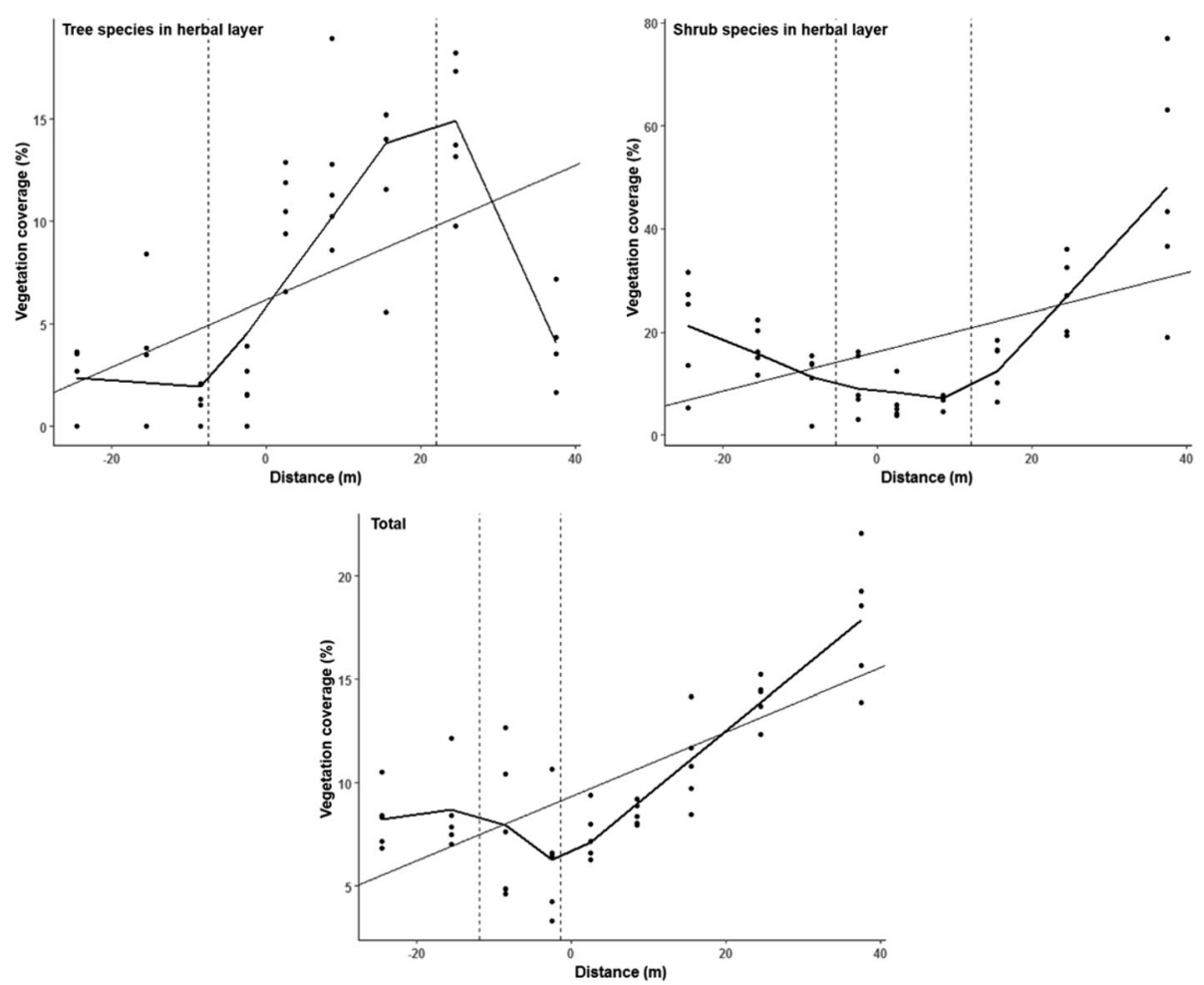

Fig. 7 A change of coverage of undergrowth along the distance from forest edge (tree species in herbal layer: $r^{2}=0.6984$, shrub species in herbal layer: $r^{2}=0.6751$, total vegetation area in herbal layer: $r^{2}=0.754$, black thick line: piecewise regression, dotted line: two break points)

Table 1 Estimates of the edge effect distance and approximate 95\% confidence intervals (Cl) for abiotic and biotic factors $\left(r^{2}>0.6\right)$

\begin{tabular}{|c|c|c|c|c|}
\hline & & $\begin{array}{l}\text { Interior (m) } \\
( \pm 95 \% \mathrm{Cl})\end{array}$ & $\begin{array}{l}\text { Exterior } \\
(\mathrm{m}) \\
( \pm 95 \% \mathrm{Cl})\end{array}$ & $\begin{array}{l}\text { Edge effect } \\
\text { distance }(m)\end{array}$ \\
\hline \multirow{9}{*}{$\begin{array}{l}\text { Abiotic } \\
\text { factors }\end{array}$} & Air humidity & $-13.6( \pm 4.7)$ & $-1.6( \pm 3.2)$ & 12.0 \\
\hline & Soil temperature & $7.6( \pm 6.8)$ & $15.8( \pm 6.7)$ & 8.2 \\
\hline & Canopy openness & $-5.5( \pm 1.4)$ & $11.3( \pm 1.2)$ & 16.8 \\
\hline & Transmitted light & $-4.7( \pm 1.5)$ & $12.1( \pm 1.6)$ & 16.8 \\
\hline & Total nitrogen & $-10.0( \pm 53.7)$ & $21.4( \pm 7.5)$ & 31.4 \\
\hline & $\mathrm{K}^{+}$ & $-14.1( \pm 43.0)$ & $14( \pm 10.8)$ & 28.1 \\
\hline & $\mathrm{Na}^{+}$ & $-4.4( \pm 3.1)$ & $4.0( \pm 2.8)$ & 8.4 \\
\hline & $\mathrm{Ca}^{2+}$ & $2.5( \pm 32.1)$ & $20.0( \pm 7.0)$ & 17.5 \\
\hline & $\mathrm{Mg}^{2+}$ & $-12.9( \pm 20.9)$ & $20.1( \pm 8.8)$ & 33.0 \\
\hline \multirow{6}{*}{$\begin{array}{l}\text { Biotic } \\
\text { factors }\end{array}$} & Species diversity & $8.2( \pm 14.4)$ & $23( \pm 16.9)$ & 14.8 \\
\hline & Species evenness & $7.8( \pm 26.9)$ & $22.9( \pm 23.3)$ & 15.1 \\
\hline & Species richness & $-3.2( \pm 10.6)$ & $3.6( \pm 14.3)$ & 6.8 \\
\hline & $\begin{array}{l}\text { Tree species in herbal } \\
\text { layer }\end{array}$ & $-7.6( \pm 8.4)$ & $21.9( \pm 4.2)$ & 29.5 \\
\hline & $\begin{array}{l}\text { Shrub species in } \\
\text { herbal layer }\end{array}$ & $-5.5( \pm 29.7)$ & $12( \pm 7.8)$ & 17.5 \\
\hline & $\begin{array}{l}\text { Total vegetation } \\
\text { coverage in herbal } \\
\text { layer }\end{array}$ & $-11.9( \pm 13.0)$ & $-1.4( \pm 4.8)$ & 10.5 \\
\hline
\end{tabular}

stable air, which allows more extreme temperature and humidity (Chen et al. 1993).

The pattern of microclimate apparently mirrors that of light exposure because solar radiation causes soil heating (Davies-colley et al. 2000). Our finding of edge effect on canopy openness and light intensity is closely comparable with that of Delado et al. (2007) who reported that the edge effects on canopy openness and light intensity may penetrate as much as 10 and $5 \mathrm{~m}$ into Canary island pine (Pinus canariensis) stand. The edge effects on canopy openness and light intensity are more influential in forest interior than in forest exterior, showing complete change over about $10 \mathrm{~m}$ exterior forest (Fig. 4).

Total nitrogen contents in forest interior and edge were similar to previous research, which was carried out in a Pinus densiflora-Quercus mongolica community of Korea (Korea Forest Service 2007). There was little difference in the average value between forest interior and edge, but the edge area showed a greater variation than forest interior. Clear-cutting influences nutrient contents, which are released from decomposing logging residues (Palviainen et al. 2004), soil microorganisms, and soil structure, which are occupied by tree roots (Keenan and Kimmins 1993).

$\mathrm{Ca}^{2+}, \mathrm{Mg}^{2+}$, and $\mathrm{K}^{+}$contents showed a notable difference between forest interior and exterior, but no any 

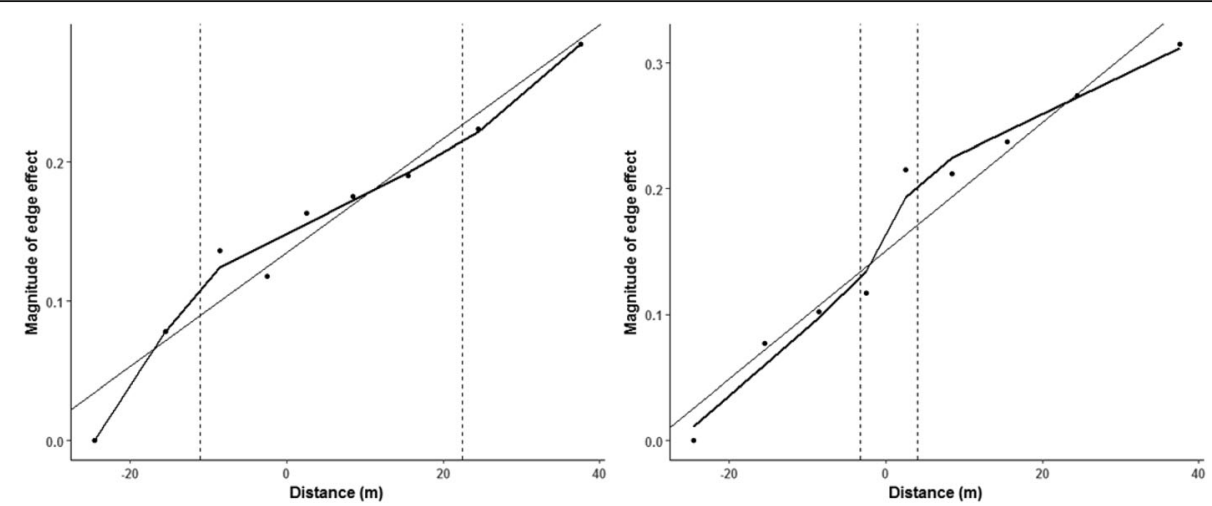

Fig. 8 A change of magnitude of edge effect according to the distance from forest edge (left: with all factors, $r^{2}=0.9860$; right: with significant factors, $r^{2}=0.9828$, black thick line: piecewise regression, dotted line: two break points)

difference between forest interior and edge. This result due to the lowered $\mathrm{pH}$ in forest interior because of pine trees composing of the forest (Hur and Joo 2002) was similar to that of Lippok et al. (2014) (Fig. 5).

Soil of forest interior have higher exchangeable $\mathrm{Na}^{+}$than that of forest exterior. But other studies showed that there was no significant difference between forest interior and exterior (Johnson et al. 1991). Therefore, further studies are required in order to make a conclusive determination for edge effect of this element.

\section{Edge effect on biotic factors}

Species richness, diversity, and evenness in herb layer rapidly increased in edge area (Fig. 6). Edge effect on plant community tends to promote the establishment of generalist species and light-demanding species (Alignier et al. 2014) and consequently reconstruction of species composition due to abiotic changes (van Oijen et al. 2005). Although species diversity and evenness in herb layer decreased in forest exterior, species richness was usually higher in forest exterior. Canopy open increases open habitat species and consequently it contributed to increasing species richness with regeneration of dominant species (Fig. 6).

Coverage of tree and shrub in undergrowth increased due to regeneration of woody plant after clear-cutting (Wendel 1975, Johnson 1977). Total coverage of undergrowth was relatively in a steady state in the forest

Table 2 Estimates of the distance of edge influence and approximate 95\% confidence intervals (Cl) $\left(r^{2}>0.6\right)$

\begin{tabular}{lllll}
\hline & & $\begin{array}{l}\text { Interior }(\mathrm{m}) \\
( \pm 95 \% \mathrm{Cl})\end{array}$ & $\begin{array}{l}\text { Exterior } \\
(\mathrm{m}) \\
( \pm 95 \% \mathrm{Cl})\end{array}$ & $\begin{array}{l}\text { Edge effect } \\
\text { distance }(\mathrm{m})\end{array}$ \\
\hline $\begin{array}{l}\text { Magnitude of } \\
\text { edge influence }\end{array}$ & $\begin{array}{l}\text { Significant } \\
\text { factors }\end{array}$ & $-3.3( \pm 19.3)$ & $4.0( \pm 13.3)$ & 7.3 \\
& All factors & $-11.0( \pm 15.7)$ & $22.4( \pm 41.1)$ & 33.4 \\
\hline
\end{tabular}

Significant factors: 15 factors $\left(r^{2}>0.6\right)$, All factors: 26 factors interior, whereas it increased when it was becoming far from the forest edge in the harvest area. Total coverage of undergrowth tended to increase rapidly after lumbering (Marozas et al. 2005, Fig. 7).

\section{Forest management strategy depending on magnitude of edge effect}

The responses of species to ecotones and correspondingly to edge effects occur on both sides of an edge located on forest interior and exterior (Zurita et al. 2012). Overall estimates of DEI toward forest interior and exterior was 11 and $22 \mathrm{~m}$, respectively.

Species composition in forest edge showed a feature that forest interior and exterior are mixed. But there was a difference between forest edge and exterior as sprouts of woody plant (Q. mongolica) were generated from stump and thereby occupied high coverage on forest floor after clear-cutting. In addition, vines ( $R$. crataegifolius and $V$. amurensis) preferring open and disturbed areas had significant impacts on change of species composition (Suzuki 1987, Krestov et al. 2015). Although other studies (Harper et al., 2005, McDonald and Urban 2006) showed that creating edge area induced invasion of exotic species, we did not find any exotic species in this study site as it is protected as a forest genetic resource reserve.

Forest interior habitat lies within the influence of both abiotic and biotic edge effects. Therefore, we need forest management to sustain the viability of the plant and animal communities that depend on stable conditions. We recommend selective logging as a harvesting method within $20 \mathrm{~m}$ from the remaining forest based on DEI obtained from this study for minimizing edge effects (Fig. 8). Selective logging in edge area toward forest exterior contributes to control light availability (Matlack 1993) and wind regime, which are key factors affecting microclimate (Davies-Colley et al. 2000, Fig. 8, Table 2). 


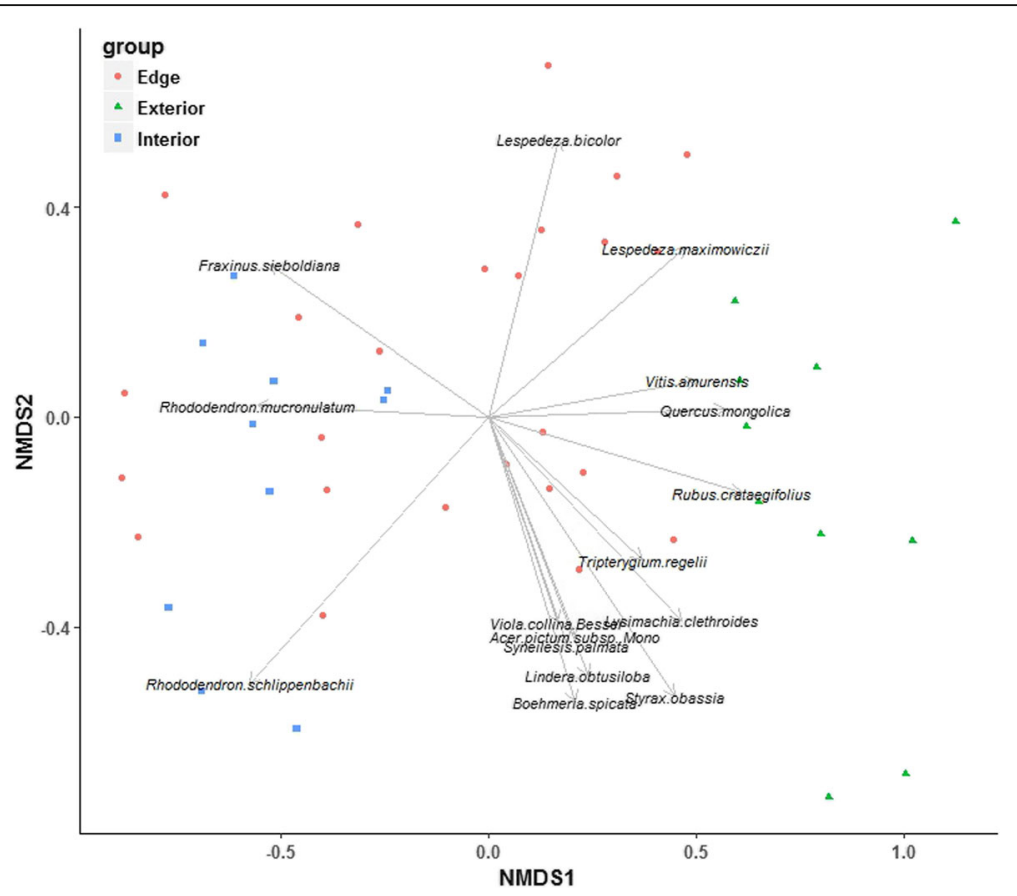

Fig. 9 NMDS biplot of sites (stress $=0.1724$ ) and environmental variables. All species variables had significant impacts on community differences (based on 1000 permutations, $p=0.001$ )

In addition, protective planting could be applied as a measure to prevent continuous disturbance in forest interior in the clear-cut area.

\section{Conclusions}

First of all, this study was carried out to evaluate the magnitude of edge effect that lumbering caused. Further, we recommend a forest management strategy to sustain stable forest ecosystem by minimizing the effect. Based on the results of this study, lumber harvest changed abiotic factors such as physicochemical properties of soil, atmospheric humidity, and light intensity and thereby induced edge effect. Further, it also caused changes of biotic factors including species composition from forest margin into forest interior. The result of evaluation on the edge effect by synthesizing both abiotic and biotic factors clarified that the magnitude of edge effect reaches up to $11 \mathrm{~m}$ of forest interior. The result of stand ordination based on vegetation data represented that shade-intolerant species tended to increase on both forest edge and harvested sites. Selective cutting rather than clear-cutting was recommended as a harvesting method to reduce edge effect in the area bordered on the remaining forest. Further, ecological restoration applying protective planting was suggested as another forest management strategy to prevent continuous disturbance like invasion and expansion of exotic species following forest edge formation into the forest interior.

\section{Abbreviations}

C: Closed forest; DEl: Distance of edge influence; MEl: Magnitude of edge influence; O: Open area

\section{Acknowledgements}

Not applicable.

\section{Funding}

This research was supported by Research Program through the Korea National Arboretum (KNA-16-C-32) funded by the Korea Forest Service.

\section{Availability of data and materials}

The datasets generated during and/or analyzed during the current study are available from the corresponding author on reasonable request.

\section{Authors' contributions}

$\mathrm{LCH}, \mathrm{KHJ}$, and CYC designed the study. $\mathrm{LCH}, \mathrm{KAR}$, and UDM collected and analyzed the data. JSH and LCS wrote the initial draft of the manuscript. All authors read and approved the final manuscript.

\section{Ethics approval}

Not applicable.

\section{Consent for publication}

Not applicable.

\section{Competing interests}

The authors declare that they have no competing interests.

\section{Publisher's Note}

Springer Nature remains neutral with regard to jurisdictional claims in published maps and institutional affiliations.

\section{Author details}

'Department of Bio and Environmental Technology, Graduate School of Seoul Women's University, Seoul 139-774, South Korea. ${ }^{2}$ Division of Ecological Assessment, National Institute of Ecology, Seocheon, 
Chungcheongnam-do 33657, South Korea. ${ }^{3}$ Research Planning and Coordination, Korea National Arboretum, Pocheon, Gyeonggi-do 11886, South Korea. ${ }^{4}$ Plant Conservation Division, Korea National Arboretum, Pocheon, Gyeonggi-do 11886, South Korea. ${ }^{5}$ Division of Chemistry and Bio-Environmental Sciences, Seoul Women's University, Seoul 139-774, South Korea.

\section{Received: 12 July 2017 Accepted: 29 August 2017}

\section{Published online: 20 October 2017}

\section{References}

Alignier, A., Alard, D., Chevalier, R., \& Corcket, E. (2014). Can contrast between forest and adjacent open habitat explain the edge effects on plant diversity? Acta Botanica Gallica., 161, 253-259.

Bekku, Y., Koizumi, H., Oikawa, T., \& Iwaki, J. (1997). Examination of four methods for measuring soil respiration. Applied Soil Ecology, 5, 247-254.

Braun-Blanquet, J. (1964). Pflanzensoziologie, Grundzüge der Vegetationskunde (Dritte Auflage ed.). Wien-New York: Springer Verlag.

Brower, J., \& Zar, J. (1984). Community similarity. In B. R. O. W. E. R. JE \& Z. A. R. JH (Eds.), Field \& Laboratory for General Ecology Dubuque (pp. 161-164). Win C Brown Publishers.

Chapman H. (1965) Cation-exchange capacity. Methods of soil analysis Part 2 Chemical and microbiological properties :891-901.

Chen, J., Franklin, J. F., \& Spies, T. A. (1993). Contrasting microclimates among clearcut, edge, and interior of old-growth Douglas-fir forest. Agricultural and Forest Meteorology, 63, 219-237.

Cochrane, M. A., \& Laurance, W. F. (2002). Fire as a large-scale edge effect in Amazonian forests. Journal of Tropical Ecology, 18, 311-325.

Davies-Colley, R., Payne, G., \& Van Elswijk, M. (2000). Microclimate gradients across a forest edge. New Zealand Journal of Ecology, 111-121.

Delgado, J. D., Arroyo, N. L., Arévalo, J. R., \& Fernández-Palacios, J. M. (2007). Edge effects of roads on temperature, light, canopy cover, and canopy height in laurel and pine forests (Tenerife, Canary Islands). Landscape and Urban Planning, 81, 328-340.

Ewers, R. M., \& Didham, R. K. (2006). Confounding factors in the detection of species responses to habitat fragmentation. Biological Reviews, 81, 117-142.

Ewers, R. M., Thorpe, S., \& Didham, R. K. (2007). Synergistic interactions between edge and area effects in a heavily fragmented landscape. Ecology, 88, 96-106.

Gascon, C., Williamson, G. B., \& da Fonseca, G. A. (2000). Receding forest edges and vanishing reserves. Science, 288, 1356-1358.

Gates, J. E., \& Gysel, L. W. (1978). Avian nest dispersion and fledging success in field-forest ecotones. Ecology, 59, 871-883.

Geiger R. The Climate near the Ground, Cambr Mass; 1965

Harper, K. A., \& Macdonald, S. (2011). Quantifying distance of edge influence: a comparison of methods and a new randomization method. Ecosphere., 2, 1-17.

Harper, K. A., \& Macdonald, S. E. (2001). Structure and composition of riparian boreal forest: new methods for analyzing edge influence. Ecology, 82, 649-659.

Harper, K. A., Lesieur D., Bergeron Y., \& Drapeau P. (2004). Forest structure and composition at young fire and cut edges in black spruce boreal forest. Canadian Journal of Forest Research, 34(2), 289-302.

Harper, K. A., Macdonald, S. E., Burton, P. J., Chen, J., Brosofske, K. D., Saunders, S. C., Euskirchen, E. S., Roberts, D., Jaiteh, M. S., \& Esseen, P. A. (2005). Edge influence on forest structure and composition in fragmented landscapes. Conservation Biology, 19, 768-782.

Harper, K. A., Macdonald, S. E., Mayerhofer, M. S., Biswas, S. R., Esseen, P. A.r, Hylander, K., Stewart, K. J., Mallik, A. U., Drapeau, P., \& Jonsson, B. G. (2015). Edge influence on vegetation at natural and anthropogenic edges of boreal forests in Canada and Fennoscandia. Journal of Ecology, 103, 550-562.

Hur, T. C., \& Joo, S. H. (2002). Comparison of Soil Physical and Chemical Properties between Coniferous and Deciduous forests in Mt. Palgong. Current Research on Agriculture and. Life Sciences, 20.

Johnson, C. E., Johnson, A. H., \& Siccama, T. G. (1991). Whole-tree clear-cutting effects on exchangeable cations and soil acidity. Soil Science Society of America Journal, 55, 502-508.

Johnson, P. S. (1977). Predicting oak stump sprouting and sprout development in the Missouri Ozarks. Dept. of Agriculture, Forest Service, North Central Forest Experiment Station.

Keenan, R. J., \& Kimmins, J. (1993). The ecological effects of clear-cutting. Environmental Reviews, 1, 121-144.

Kim, J. S. (2010). Edge effects on vegetation and environment after clearcutting of Pinus densiflora forest Graduate school of science and technology.
Kim, J. S. (2014). A Study on Stand Structure, Environmental factor and Understory vegetation for Variable Retention in Quercus mongolica Forest. Graduate school of science and technology.

Korea Forest Service. (2007). The policies and the efficient cultivation plan for Pinus densiflora. Korea Forest Service.

Korea Meteorological Administration. (2011). 2011 Annual climatological report. Korea Meteorological Administration.

Krestov, P., Omelko, A. M., Ukhvatkina, O., \& Nakamura, Y. (2015). Temperate summergreen forests of East Asia. Ber Reinhold-Tüxen-Ges., 27, 133-145.

Kruskal, J. B. (1964). Multidimensional scaling by optimizing goodness of fit to a nonmetric hypothesis. Psychometrika, 29, 1-27.

Laurance, W. F., Ferreira, L. V., Rankin-de Merona, J. M., \& Laurance, S. G. (1998). Rain forest fragmentation and the dynamics of Amazonian tree communities. Ecology, 79, 2032-2040.

Laurance, W. F., Lovejoy, T. E., Vasconcelos, H. L., Bruna, E. M., Didham, R. K., Stouffer, P. C., Gascon, C., Bierregaard, R. O., Laurance, S. G., \& Sampaio, E. (2002). Ecosystem decay of Amazonian forest fragments: a 22-year investigation. Conservation Biology, 16, 605-618.

Laurance, W. F., Nascimento, H. E., Laurance, S. G., Andrade, A., Ribeiro, J. E. Giraldo, J. P., Lovejoy, T. E., Condit, R., Chave, J., \& Harms, K. E. (2006). Rapid decay of tree-community composition in Amazonian forest fragments. Proceedings of the National Academy of Sciences of the United States of America, 103, 19010-19014.

Laurance, W. F., Williamson, G. B., Delamônica, P., Oliveira, A., Lovejoy, T. E., Gascon, C., \& Pohl, L. (2001). Effects of a strong drought on Amazonian forest fragments and edges. Journal of Tropical Ecology, 17, 771-785.

Lee, C. B. (1985). Illustrated flora of Korea. Seoul: Hangmun Pub Co.

Lee, R. (1978). Forest microclimatology. Columbia University Press.

Lippok, D., Beck, S. G., Renison, D., Hensen, I., Apaza, A. E., \& Schleuning, M. (2014) Topography and edge effects are more important than elevation as drivers of vegetation patterns in a neotropical montane forest. Journal of Vegetation Science, 25, 724-733.

MacQuarrie, K., \& Lacroix, C. (2003). The upland hardwood component of Prince Edward Island's remnant Acadian forest: determination of depth of edge and patterns of exotic plant invasion. Canadian Journal of Botany, 81, 1113-1128.

MAPA MOdA. (1994). Tomo III. Ministerio de Agricultura, pesca, y Alimentación Madrid, Ministerio de Agricultura, pesca, y Alimentación Madrid.

Margalef, R. (1958). Temporal succession and spatial heterogeneity in phytoplankton. University of California press.

Marozas, V., Grigaitis, V., \& Brazaitis, G. (2005). Edge effect on ground vegetation in clear-cut edges of pine-dominated forests. Scandinavian Journal of Forest Research, 20, 43-48.

Matlack, G. R. (1993). Microenvironment variation within and among forest edge sites in the eastern United States. Biological Conservation, 66, 185-194.

McCune, B., \& Mefford, M. J. (1999). PC-ord. Multivariate analysis of ecological data, version 4.

McDonald, R. I., \& Urban, D. L. (2006). Edge effects on species composition and exotic species abundance in the North Carolina Piedmont. Biological Invasions, 8, 1049-1060.

Ming, Z., Kim, J. S., Cho, Y. C., Bae, S. W., Yun, C. W., Byun, B. K., \& Bae, K. H. (2013) Initial Responses of Understory Vegetation to $15 \%$ Aggregated Retention Harvest in Mature Oak (Quercus mongolica) Forest in Gyungsangbukdo. J Korean For Soc., 102, 239-246.

Murphy, J., \& Riley, J. P. (1962). A modified single solution method for the determination of phosphate in natural waters. Analytica Chimica Acta, 27, 31-36.

Palviainen, M., Finér, L., Kurka, A.-M., Mannerkoski, H., Piirainen, S., \& Starr, M. (2004). Decomposition and nutrient release from logging residues after clearcutting of mixed boreal forest. Plant and Soil, 263, 53-67.

Park, S. G., Oh, G., \& Sin, H. T. (2010). Effects of Light Condition on the Vegetation Restoration by Clear Cutting in a Larch Plantation. In Proceedings of the Korean Society of Environment and Ecology Conference. Korean Journal of Environment and Ecology.

Park, Y. D., \& Yoon, H. D. (1968). Geological Map of Korea (1: 50,000)-Uljin. Korea Institute of Geology, Mining, and Materials

Pielou, E. C. (1969). An introduction to mathematical ecology. An introduction to mathematical ecology.

Pohlman, C. L., Turton, S. M., \& Goosem, M. (2007). Edge effects of linear canopy openings on tropical rain forest understory microclimate. Biotropica, 39, 62-71.

Pykälä, J. (2004). Immediate increase in plant species richness after clear-cutting of boreal herb-rich forests. Applied Vegetation Science, 7, 29-34. 
Saunders, D. A., Hobbs, R. J., \& Margules, C. R. (1991). Biological consequences of ecosystem fragmentation: a review. Conservation Biology, 5, 18-32.

Shannon, C. E., \& Weaver, W. (1949). The mathematical theory of information. Suzuki, W. (1987). Comparative ecology of Rubus species (Rosaceae) I. ecological distribution and life history characteristics of three species, R. palmatus var. coptophyllus, R. microphyllus and R. crataegifolius. Plant Species Biology, 2, 85-100

Toms, J. D., \& Lesperance, M. L. (2003). Piecewise regression: a tool for identifying ecological thresholds. Ecology, 84, 2034-2041.

Turton, S. M., \& Freiburger, H. J. (1997). Edge and aspect effects on the microclimate of a small tropical forest remnant on the Atherton Tableland, northeastern Australia. University of Chicago Press.

van Oijen, D., Feijen, M., Hommel, P., den Ouden, J., de Waal, R., \& Hermy, M. (2005). Effects of tree species composition on within-forest distribution of understorey species. Applied Vegetation Science, 8, 155-166.

Wales, B. A. (1972). Vegetation Analysis of North and South Edges in a Mature Oak-Hickory Forest. Ecological Monographs, 42, 451-471.

Walkley, A., \& Black, I. A. (1934). An examination of the Degtjareff method for determining soil organic matter, and a proposed modification of the chromic acid titration method. Soil Science, 37, 29-38.

Wendel, G. (1975). Stump sprout growth and quality of several Appalachian hardwood species after clearcutting. U.S. Dept. of Agriculture, Forest Service, Northeastern Forest Experiment Station.

Young, A., \& Mitchell, N. (1994). Microclimate and vegetation edge effects in a fragmented podocarp-broadleaf forest in New Zealand. Biological Conservation, 67, 63-72.

Zurita, G., Pe'er, G., Belloca, M. I. \& Hansbauer, M. M. (2012). Edge effects and their influence on habitat suitability calculations: a continuous approach applied to birds of the Atlantic forest. Journal of Applied Ecology, 49, 503-512.

\section{Submit your next manuscript to BioMed Central and we will help you at every step:}

- We accept pre-submission inquiries

- Our selector tool helps you to find the most relevant journal

- We provide round the clock customer support

- Convenient online submission

- Thorough peer review

- Inclusion in PubMed and all major indexing services

- Maximum visibility for your research

Submit your manuscript at www.biomedcentral.com/submit

C) Biomed Central 